\title{
OTWARTE CZASOPISMA W NAUKACH TECHNICZNYCH
}

\begin{abstract}
In the paper, the comparison of scientific output as articles - between researchers from the Lodz University of Technology Faculty of Mechanical Engineering and the Lodz University of Technology Institute of Physics, is showed respectively. Furthermore, the dependence on articles published within decade versus employment can be found too.
\end{abstract}

Słowa kluczowe: open access, czasopisma naukowe, repozytoria instytucjonalne

\section{Wstęp}

Biblioteki akademickie są inicjatorami, organizatorami i głównymi koordynatorami repozytoriów uczelnianych. Wynika to z faktu, że posiadają one fachową wiedzę potrzebną między innymi do tworzenia, przetwarzania i zarządzania metadanymi wraz z powiązanymi z nimi pełnymi tekstami publikacji. Praktyczna znajomość prawa autorskiego i otwartych licencji, dzięki doświadczeniom nabytym przy projektach bibliotek cyfrowych, jest także wyróżniającym je atutem. Dodatkowo, zasób repozytorium jest istotnym elementem każdego CRIS (Current Research Information System).

Do analizy wybrano artykuły polskie oraz zagraniczne pracowników naukowych Wydziału Mechanicznego oraz Instytutu Fizyki Politechniki Łódzkiej (odpowiednio: WM PŁ i IF PŁ), opublikowane w latach 2004-2014 (tab.1). Do badań wykorzystano zawartość bazy BIBLIO Dorobku Piśmienniczego Pracowników Politechniki Łódzkiej ${ }^{1}$ - tworzonej w systemie Expertus. W bazie rejestrowane są różnego typu publikacje, w tym: artykuły, wydawnictwa zwarte autorskie, referaty na konferencjach, prace zbiorowe, materiały konferencyjne, utwory w wydawnictwach zwartych, recenzje, patenty, czasopisma (redakcje).

Prawie 50\% wszystkich publikacji stanowią artykuły, zarówno w przypadku pracowników naukowych IF PŁ, jak i WM PŁ. W dorobku naukowym fizyków - 32\% wszystkich artykułów pochodzi z czasopism z Impact Factor (IF). Dla mechaników ten odsetek wynosi 12\% (tab. 2).

\footnotetext{
${ }^{1}$ Baza BIBLIO, [dostęp: 21.03.2015], http://212.51.210.184/ expertus/e/index.php.
} 
Tabela 1

Dorobek piśmienniczy pracowników IF PŁ - zestawienie dla artykułów

\begin{tabular}{|l|c|c|c|c|c|}
\hline & $\begin{array}{c}\text { lączna } \\
\text { liczba prac }\end{array}$ & $\begin{array}{c}\text { \% udzial } \\
\text { artykulów } \\
\text { w dorobku }\end{array}$ & $\begin{array}{c}\text { \% udzial } \\
\text { prac z IF }\end{array}$ & $\begin{array}{c}\text { ziczba } \\
\text { artykulów } \\
\text { z czasopism } \\
\text { z IF }\end{array}$ & $\begin{array}{c}\text { lączna } \\
\text { wartość IF }\end{array}$ \\
\hline ogółem & 968 & \multirow{2}{*}{$49 \%$} & 153 & \multirow{2}{*}{$32 \%$} & 273,030 \\
\cline { 1 - 1 } & & & $\mathbf{1 4 9}$ & & 265,320 \\
\hline
\end{tabular}

Źródło: oprac. własne.

Tabela 2

Dorobek piśmienniczy pracowników WM PŁ - zestawienie dla artykułów

\begin{tabular}{|l|c|c|c|c|c|}
\hline & $\begin{array}{c}\text { lączna } \\
\text { liczba prac }\end{array}$ & $\begin{array}{c}\text { \% udzial } \\
\text { artykulów } \\
\text { w dorobku }\end{array}$ & $\begin{array}{c}\text { liczba } \\
\text { prac z IF }\end{array}$ & $\begin{array}{c}\text { \% udzial } \\
\text { artykulów } \\
\text { z czasopism } \\
\mathbf{z} \text { IF }\end{array}$ & $\begin{array}{c}\text { lączna } \\
\text { wartość } \\
\text { IF }\end{array}$ \\
\hline ogółem & 5466 & \multirow{2}{*}{$46 \%$} & 305 & \multirow{2}{*}{$12 \%$} & 504,938 \\
\cline { 1 - 1 } & & $\mathbf{3 0 2}$ & & 502,210 \\
\hline
\end{tabular}

Źródło: oprac. własne.

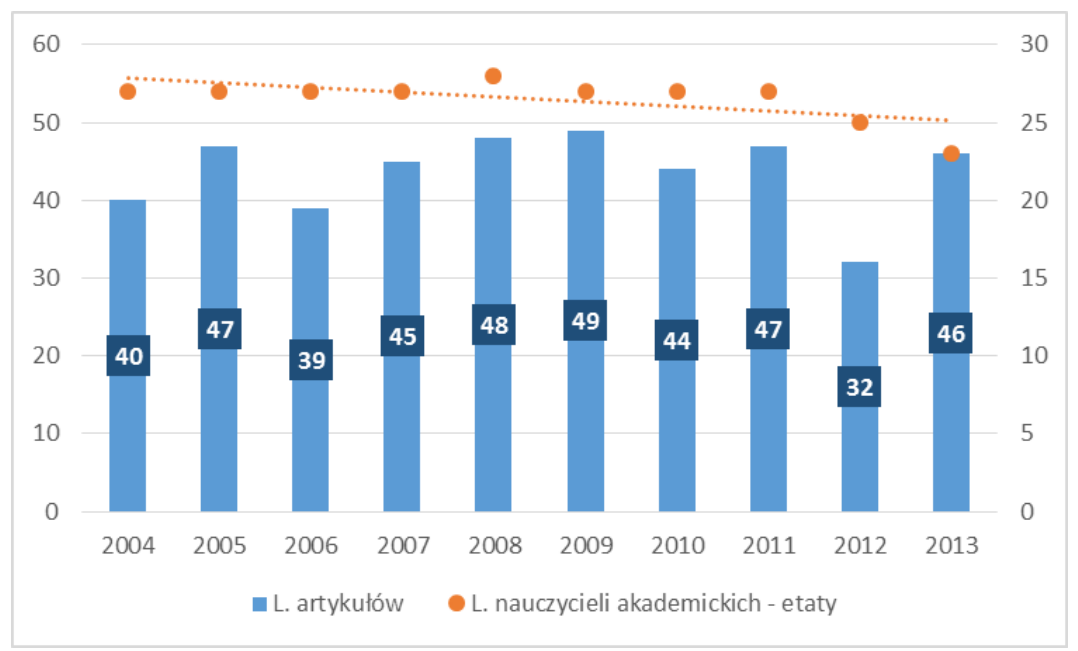

Rys. 1. Liczba nauczycieli akademickich w IF PŁ vs liczba artykułów Źródło: oprac. własne. 


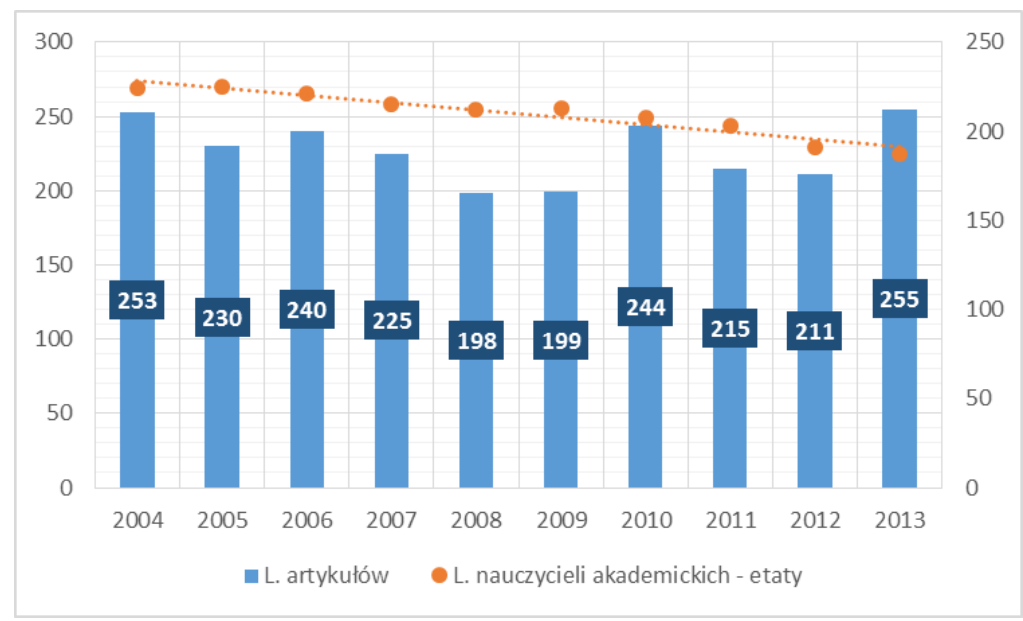

Rys. 2. Liczba nauczycieli akademickich na WM PŁ vs liczba artykułów Źródło: oprac. własne.

Zmiany etatowe zatrudnienia $\mathrm{w}$ obu omawianych jednostkach $\mathrm{w}$ latach 2004-2013 ${ }^{2}$ wraz z rozkładem artykułów w odpowiednich rocznikach przedstawiono na rys. 1 i 2.

Liczba nauczycieli akademickich prezentowana na powyższych wykresach odpowiada pełnym etatom. Do tej grupy zaliczają się: profesorowie z tytułem, doktorzy habilitowani na stanowisku profesora nadzwyczajnego, doktorzy habilitowani niebędący profesorami, nauczyciele akademiccy ze stopniem doktora oraz pozostali nauczyciele akademiccy.

W IF PŁ w latach 2004-2011 liczba etatów nauczycieli akademickich utrzymywała się na poziomie: 27-28, dopiero w latach 2012 i 2013 następuje zauważalny spadek do 25 i następnie do 23 etatów. W 2012 r. można też zaobserwować najmniejszą liczbę artykułów opublikowanych przez pracowników naukowych -32 .

Inaczej jest w przypadku WM PŁ - przez kolejne lata - 2005-2013, liczba etatów nauczycieli akademickich ulega stopniowemu zmniejszaniu. W 2008 oraz 2009 r. pracownicy tego wydziału opublikowali najmniejszą liczbę artykułów: 198-199. Ciekawy wynik można zaobserwować w 2013 r. - przy najmniejszej liczbie etatów od 2004 r. - 187, opublikowano największą liczbę artykułów - 255. Należy jednak zauważyć, że w ramach jednego etatu może być zatrudnionych dwóch pracowników naukowych.

W ostatniej dekadzie pracownicy naukowi Instytutu Fizyki PŁ opublikowali łącznie 470 artykułów, w 128 różnych tytułach.

\footnotetext{
${ }^{2}$ Sprawozdania z działalności Politechniki Łódzkiej w latach 2004-2013 (sprawozdanie z działalności Politechniki Łódzkiej w 2014 jeszcze nie zostało udostępnione), [dostęp: 6.04.2015], portal pracowniczy Politechniki Łódzkiej, dostęp zastrzeżony dla użytkowników wewnętrznych.
} 
Najczęściej wybieranym przez nich czasopismem - 66 razy, były „Zeszyty Naukowe Politechniki Łódzkiej - seria Fizyka” (tab. 3), wydawane w latach 1973-1995 w polskiej wersji językowej, a następnie w języku angielskim od 1995 r. pod zmienionym tytułem: "Scientific Bulletin. Physics" (3 punkty za publikację według obowiązującej listy ministerialnej).

W tej samej dekadzie pracownicy naukowi Wydziału Mechanicznego PŁ opublikowali łącznie 2516 artykułów, w 446 różnych tytułach. Najczęściej wybieranym przez nich czasopismem była „Inżynieria Materiałowa”, wydawana przez SIGMA-NOT, gdzie opublikowali łącznie 207 artykułów (7 punktów za publikację według obowiązującej listy ministerialnej). Drugim najbardziej popularnym wśród naukowców PŁ tytułem okazały się „Zeszyty Naukowe Politechniki Łódzkiej - seria Cieplne Maszyny Przepływowe", wydawane od 1994 r. na bieżąco: 148 artykułów (2 punkty za publikację). Co więcej, czasopismo o tytule: "Mechanics and Mechanical Engineering" (80 artykułów) jest również wydawane przez Politechnikę Łódzką, a dokładniej - przez Katedrę Dynamiki Maszyn Wydziału Mechanicznego, jako kontynuacja tytułu "Scientific Bulletins. Mechanical Engineering" od 1997 r. Zatem, aż 228 artykułów pochodzi z czasopism wydawanych przez macierzystą uczelnię (tab. 4).

Tabela 3

IF PŁ - 5 tytułów czasopism z największą liczbą artykułów

\begin{tabular}{|c|l|c|}
\hline Lp. & \multicolumn{1}{|c|}{ Tytul } & L. artykułów \\
\hline & $\begin{array}{l}\text { "Scientific Bulletin. Physics / Technical } \\
\mathbf{1}\end{array}$ & \\
\hline $\mathbf{2}$ & "Oniversity of Łódź" & 66 \\
\hline $\mathbf{3}$ & „Elektronika" Electronics Review” & 30 \\
\hline $\mathbf{4}$ & „Fizyka budowli w teorii i praktyce” & 28 \\
\hline $\mathbf{5}$ & „Optica Applicata" & 19 \\
\hline
\end{tabular}

Źródło: oprac. własne.

Tabela 4

WM PŁ - 5 tytułów czasopism z największą liczbą artykułów

\begin{tabular}{|c|c|c|}
\hline Lp. & Tytul & L. artykulów \\
\hline 1 & „Inżynieria Materiałowa” & 207 \\
\hline 2 & $\begin{array}{l}\text { „Zeszyty Naukowe PŁ. Cieplne Maszyny } \\
\text { Przepływowe” }\end{array}$ & 148 \\
\hline 3 & "Archives of Foundry Engineering", & 105 \\
\hline 4 & „Inżynieria Biomateriałów” & 87 \\
\hline 5 & "Mechanics and Mechanical Engeneering" & 80 \\
\hline
\end{tabular}

Źródło: oprac. własne. 
Jednocześnie, na 128 tytułów czasopism, w których publikowali pracownicy naukowi IF PŁ, aż w 58 przypadkach - 45\%, opublikowali oni tylko raz jeden artykuł w ciągu 10 lat. Podobnie jest w przypadku pracowników naukowych WM PŁ - wskaźnik ten wyniósł blisko 47\% - w 209 tytułach czasopism nie złożyli oni po raz drugi do publikacji żadnego artykułu. Przyczyn tego zjawiska może być kilka ${ }^{3}$ :

- $\quad$ zbyt długi okres oczekiwania na publikację od momentu złożenia manuskryptu;

- $\quad$ zmiana punktacji MNiSW na mniej korzystną za artykuł;

- $\quad$ zmiana IF dla czasopisma na mniej korzystny;

- $\quad$ ogólne niezadowolenie z przebiegu i obsługi procesu wydawniczego, na przykład współpraca z redaktorami, opinie recenzentów, złożone formatowanie tekstu;

- $\quad$ zakończenie działalności czasopisma lub/i wydawnictwa;

- zmiana trendów publikowania $\mathrm{z}$ określonej tematyki w danym czasopiśmie;

- $\quad$ zmiana zainteresowań badawczych;

- inne.

Oczywistym jest, że w kolejnych latach, po 2014 r., wyniki ilościowe mogą ulegać zmianie - gdyż w czasopiśmie, w którym opublikowano tylko raz jeden artykuł - zostaną złożone do publikacji następne.

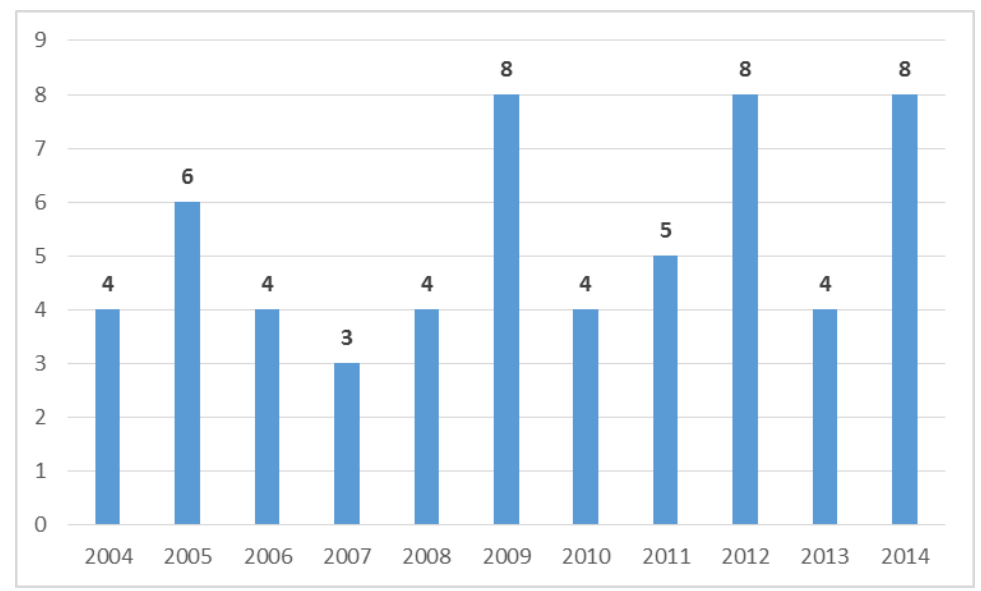

Rys. 3. Rozkład liczby tytułów czasopism,

w których tylko raz dokonano publikacji w latach 2004-2014 - dane dla IF PŁ Źródło: oprac. własne.

Niemniej jednak, na podstawie analizy zakresu lat 2004-2014, można zaobserwować prawidłowość, że czasopismo, w którym przestano publikować, nie staje się na nowo popularne wśród badaczy. Na wykresach - rys. 3 i 4

\footnotetext{
${ }^{3}$ Propozycja autorki.
} 
zaprezentowano roczny rozkład tytułów czasopism, w których pracownicy naukowi PŁ opublikowali tylko raz jeden artykuł w ciągu dziesięciu lat, odpowiednio dla IF PŁ i WM PŁ.

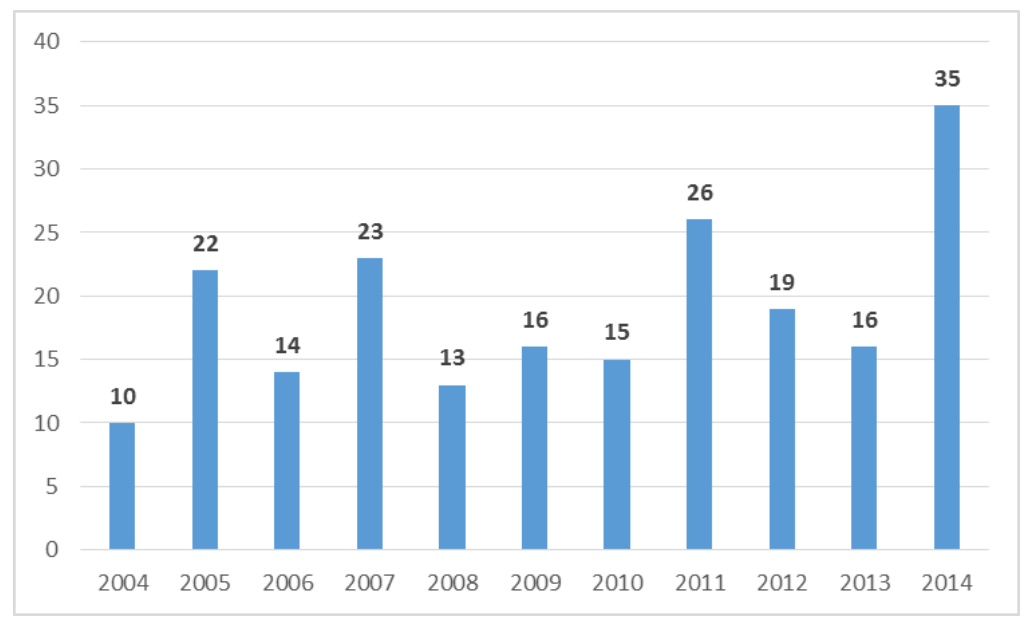

Rys. 4. Rozkład liczby tytułów czasopism,

w których tylko raz dokonano publikacji w latach 2004-2014 - dane dla WM PE

Źródło: oprac. własne.

Dorobek piśmienniczy pracowników naukowych, zwłaszcza ten w postaci artykułów, to zasób specjalistycznej wiedzy i informacji, który jest fundamentem repozytorium instytucjonalnego każdej uczelni. Nie zawsze jednak jest ono uważane za narzędzie efektywnie wspierające wizerunek i komunikację naukową przez samo środowisko badaczy. Inną barierą są zawiłości prawa autorskiego - zwłaszcza pojęcie ich przeniesienia oraz interpretacja zapisów licencyjnych. Polityki wydawców względem zamieszczania wydanych w ich czasopismach artykułów w repozytoriach, można sprawdzić w bazie SHERPA/ $\mathrm{RoMEO}^{4}$. Jest ona polecana i zalecana dla autorów pragnących deponować swoje artykuły nie tylko $\mathrm{w}$ repozytoriach instytucjonalnych czy dziedzinowych, ale też na przykład na różnych osobistych stronach WWW i blogach naukowych. Twórcy bazy zróżnicowali kolory polityk wydawców w zależności od stopnia ich otwartości. Kolor zielony oznacza, że autor publikacji może archiwizować zarówno preprinty i postprinty lub tak zwane publisher's PDF. Kolor niebieski natomiast - odpowiada możliwości zamieszczania postprintów lub tak zwany publisher's PDF. Kolor żółty pozwala tylko na deponowanie preprintów, a kolor biały - wyraża brak zezwolenia na archiwizację artykułów opublikowanych w danym tytule czasopisma ${ }^{5}$.

\footnotetext{
${ }^{4}$ Baza SHERPA/RoMEO, [dostęp: 10.04.2015], http://www.sherpa.ac.uk/romeo/search. php.

${ }^{5}$ Zamieszczanie czasopisma w RoMEO, [dostęp: 10.04.2015], http://www.edukacja informacyjna.pl/2013/04/romeo-dla-czasopisma-i-ani-slowa-o-weronie/.
} 
Dalszą analizą w powyższym kontekście objęto tytuły czasopism, w których tylko raz opublikowany został jeden artykuł w ostatnich dziesięciu latach. Łącznie zbadano 267 tytułów czasopism. Otrzymane wyniki przedstawiono na wykresach - rys. 5 i 6,7 i 8.

W przypadku tytułów czasopism, w których publikowali pracownicy naukowi Instytutu Fizyki PŁ, 57\% z nich podlega zielonej polityce - zatem możliwe jest zamieszczanie preprintów oraz postprintów lub publisher's PDF w repozytoriach lub na stronach www. Natomiast $31 \%$ tytułów czasopism nie występuje w ogóle w bazie SHERPA/RoMEO - rys.5. Może to oznaczać, że polityka tych wydawców nie jest transparentna, albo że należy ją sprawdzić bezpośrednio u źródła ${ }^{6}$.

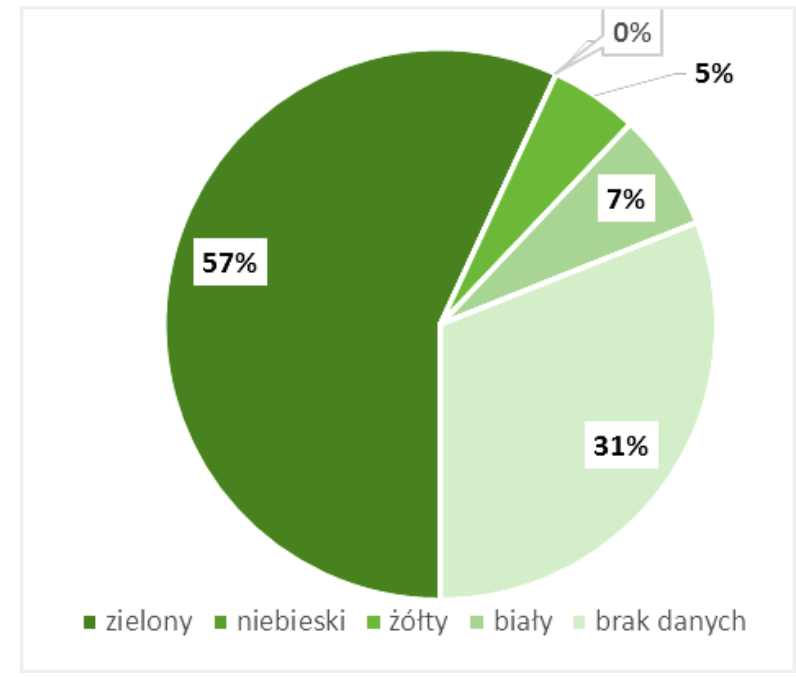

Rys. 5. Rozkład polityk wydawców według bazy SHERPA/RoMEO dla tytułów czasopism, w których tylko raz został opublikowany artykuł w latach 2004-2014 - dane dla IF PŁ

Źródło: oprac. własne.

\footnotetext{
${ }^{6}$ Wzory wniosków: uzyskanie zgody na umieszczenie w repozytorium $\mathrm{w}$ imieniu autora artykułu: [dostęp: 10.04.2015], http://www.sherpa.ac.uk/documents/request_template.html; uzyskanie zgody przez autora na umieszczenie artykułu w repozytorium: [dostęp: 10.04.2015], http://www.sherpa.ac.uk/documents/request_template.html\#author.
} 


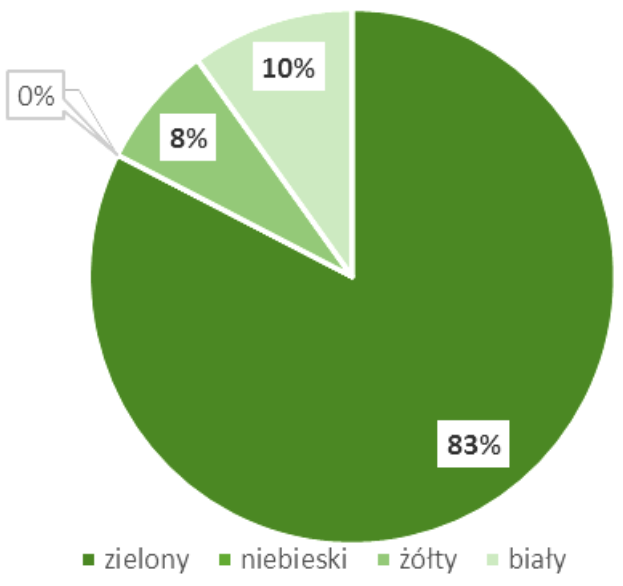

Rys. 6. Rozkład potwierdzonych polityk wydawców według bazy SHERPA/RoMEO dla tytułów czasopism, w których tylko raz został opublikowany artykuł w latach 2004-2014 - dane dla IF PŁ

Źródło: oprac. własne.

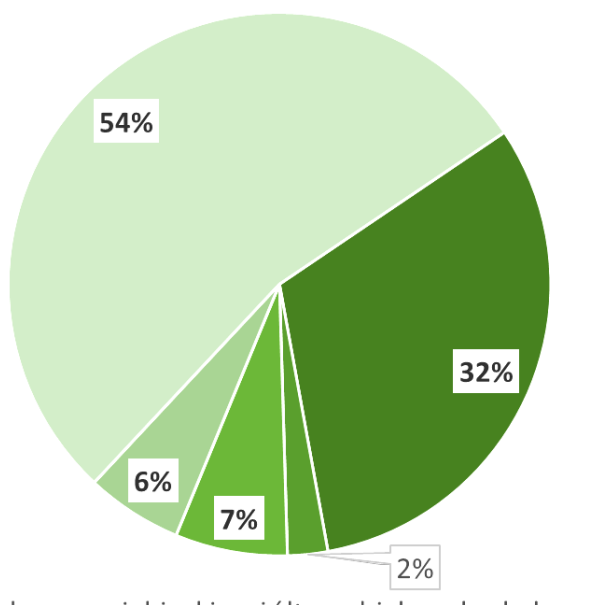

Rys. 7. Rozkład polityk wydawców według bazy SHERPA/RoMEO dla tytułów czasopism, w których tylko raz został opublikowany artykuł w latach 2004-2014 - dane dla WM PŁ

Źródło: oprac. własne. 


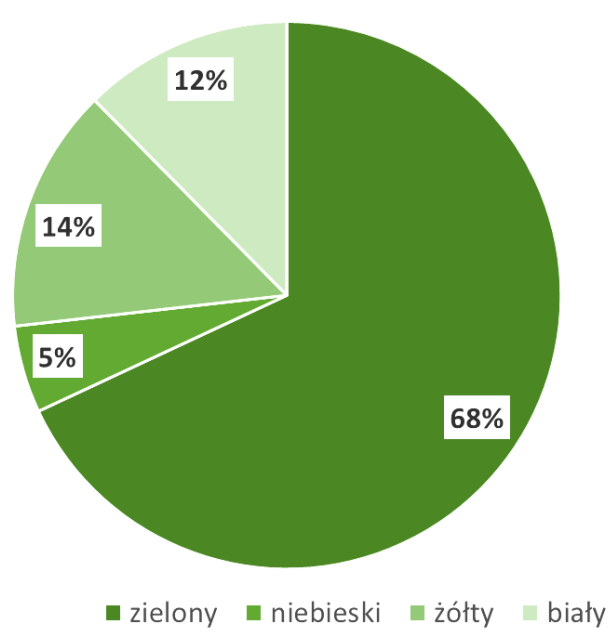

Rys. 8. Rozkład potwierdzonych polityk wydawców wg bazy SHERPA/RoMEO dla tytułów czasopism, w których tylko raz został opublikowany artykuł w latach 2004-2014 - dane dla WM PŁ

Źródło: oprac. własne.

W przypadku WM PŁ jest to $68 \%$ tytułów. Polityce niebieskiej nie podlega żaden z tytułów, w których publikują fizycy, natomiast dla mechaników wskaźnik ten wynosi 5\%. Porównywalną wartość dla białych zasad: 10-12\% uzyskano dla obu jednostek PŁ.

\section{Podsumowanie}

Przedstawione zależności mogą być przedmiotem dalszych analiz i dzięki temu zostać w pełni zweryfikowane podczas dodatkowych badań ankietowych przeprowadzonych wśród autorów artykułów. Uzyskane wyniki dotyczące otwartości tytułów czasopism, w których pracownicy naukowi opublikowali tylko raz jeden artykuł w ciągu 10 lat, mogą być uznane za obiecujące. Jednakże, w zależności od obszarów tematycznych, w których publikują oni 2 lub więcej artykuły, mogą wystąpić analogiczne znaczne różnice, na przykład jak w zielonym dostępie (57\% - IF PŁ; 32\% WM PŁ).

\section{Bibliografia}

Baza BIBLIO, [dostęp: 21.03.2015], http://212.51.210.184/ expertus/e/index.php.

Baza SHERPA/RoMEO, [dostęp: 10.04.2015], http://www.sherpa.ac.uk/romeo/search.php.

Zamieszczanie czasopisma w RoMEO, [dostęp: 10.04.2015], http://www.edukacjainformacyjna. pl/2013/04/romeo-dla-czasopisma-i-ani-slowa-o-weronie/.

Sprawozdania z działalności Politechniki Łódzkiej w latach 2004-2013 (komentarz: sprawozdanie z działalności Politechniki Łódzkiej w 2014 r. jeszcze nie zostało udostępnione), 
[dostęp: 6.04.2015], portal pracowniczy Politechniki Łódzkiej; dostęp zastrzeżony dla użytkowników wewnętrznych.

Wzory wniosków:

Uzyskanie zgody na umieszczenie $\mathrm{w}$ repozytorium $\mathrm{w}$ imieniu autora artykułu: [dostęp: 21.03.2015], http://www.sherpa.ac.uk/documents/request_template.html.

Uzyskanie zgody przez autora na umieszczenie artykułu w repozytorium: [dostęp: 1.03.2015], http://www.sherpa.ac.uk/documents/request_template.html\#author. 